\title{
Etnografický obraz Arabov v Byzancii 10. storočia
}

\author{
Mgr. Filip Schneider, MA \\ Katedra etnológie a mimoeurópskych štúdií \\ Univerzita sv. Cyrila a Metoda v Trnave
}

Orientalia Antiqua Nova XXI

ISBN 978-80-261-1039-2

Západočeská univerzita v PIzni, 2021

https://doi.org/10.24132/ZCU.2021.10392-97-119 


\section{Abstract}

Roman historians developed a tradition of placing ethnographic information into their works. The "Other" was an everyday reality of the Roman state. With its expansion more nations came into its orbit and thus to the attention of its writers. Arabs were among many others whom the Romans confronted.

The position of the Arabs changed rapidly since the emergence of Islam in the $7^{\text {th }}$ century. From a peripheral nation they became the major superpower in the East. The Roman/Byzantine perception did change due to various factors, such as the emergence of new religion as well as military expansion of the newly founded Arab state.

It was in this period when ethnographic tradition underwent a major transformation. Ethnography was in decline with snippets of information throughout literary works instead of vast descriptions of the "Other" as known in antiquity. Merging the snippets, however, a more coherent image may occur.

The aim of this paper is to look on the ethnographic information about Arabs in three literary works of the $10^{\text {th }}$ century Byzantium - the Taktika, De administrando imperio and History of Leo the Deacon. Arabs will be analysed under the scope of elements that affected Byzantine perception on them - religion, military, and ethnic stereotypes. With the analysis I intend not only to gain a more coherent picture about the ethnographic perception of the Arabs in Byzantium, but also the difference of the perception among its various social classes. 


\section{Úvod}

Rímska/Byzantská ríša konfrontovala Arabov už od dávnych čias a po zrode Islamu a následnej arabskej expanzii boli kontakty medzi oboma národmi intenzívnejšie. Byzantské pramene tak obsahujú množstvo informácií o Araboch. Oproti staroveku je však stredobyzantské obdobie chudobné na etnografické správy. Bolo to aj dôsledkom „obdobia temna“, ktoré v Byzancii nastalo práve po období arabských výbojov v 7. storočí. ${ }^{1}$

Arabi, o ktorých písali autori v 10. storočí boli iní ako tí, ktorých spomína napr. Ammianus Marcellinus. ${ }^{2}$ Typickým znakom Arabov sa stalo nové náboženstvo - Islam. Druhým rozdielom bolo to, že Arabi boli v 10. storočí hlavným východným rivalom Rímskej ríše.

Ciel'om príspevku je ukázat Arabov vo vybraných byzantských prameňoch pod vplyvom rozličných faktorov, ako sú náboženstvo, vojenstvo a etnické stereotypy. Simultánne predstaví príspevok etnografiu 10. storočia vo vybraných prameňoch, ktoré obsahujú etnografické informácie o Araboch. Nakoniec sa príspevok pokúsi cez etnografiu približit dôvody, ktoré mali vplyv na obraz Arabov $v$ rámci byzantskej literatúry.

\section{Pramene}

Výskum sa zameriava na tri pramene 10. storočia. Prvým z nich Taktika, ktorú zhotovil cisár Lev VI. Múdry (886-912) okolo roku $900 .{ }^{3}$ Ide o vojenskú príručku, ktorá je do vel'kej miery založená

\footnotetext{
${ }^{1}$ Dostálová 2003, 144.

${ }^{2}$ Ammianus Marcellinus, XIV. 4.

${ }^{3}$ Theotokis 2018, 108; O Taktike bolo napísaných viacero štúdií, ako Nakada 2017, 17-27. Aktuálne najrozsiahlejšie dielo napísal John Haldon, ktorý dopodrobna
} 
na starovekých vzoroch. ${ }^{4}$ Pre náš výskum je dôležitá konštitúcia 18, ktorá nesie názov „O praktikách rôznych l'udí a Rimanov v ich bojových formáciách“. Ako názov uvádza, ide o etnografické informácie o rôznych susedných národoch. Vedomosti o „Tých druhých“, s výnimkou Arabov, sú do vel'kej miery recykláciou zo Pseudo-Mauríkiovho Strategikonu zo 6. storočia. ${ }^{5} \mathrm{~V}$ čase zhotovenia Strategikonu boli Arabi národom niekde na periférii Rímskej riše, ktorí občas vykonali nájazd na rímske územie, prípadne niektoré arabské kmene boli v službách rímskeho štátu. ${ }^{6}$ Ked’že v 6. storočí nepredstavovali Arabi významnú vojenskú hrozbu ríše, Pseudo-Mauríkios nemal potrebu ich zaradit do svojho diela. V období Leva VI. však Arabi predstavovali hlavnú mocnost na východe, čím nahradili Peržanov. Ako bude ukázané nižšie, niektoré vlastnosti Peržanov boli aplikované na Arabov, avšak vo všeobecnosti bol Kalifát $v$ mnohých veciach odlišný od sasánovskej ríše.

Taktika obsahuje najrozsiahlejšie etnografické informácie o susedných národoch v stredobyzantskom období. Dielo zároveň odráža zvýšený trend encyklopedických diel v 10. storočí. Encyklopedické tendencie sú badatel'né aj v diele z polovice 10. storočia De administrando imperio.

Autorstvo De administrando imperio (d'alej DAI) sa pripisuje cisárovi Konštantínovi VII. Porfyrogenetovi (945-959), avšak dnes

rozobral Taktiku, pozri Haldon 2014. Vo svojej dnes už klasickej štúdií sa Kolias Taxiarchis zaoberal zobrazením Arabov v Taktike, pozri Taxiarchis 1984, 129-135.

4 Taxiarchis 1984, 129.

${ }^{5}$ Kaldellis 2013, 87.

${ }^{6}$ Možno spomenút arabský kmeň Ghassanovcov, ktorý slúžil ako konfederačný kmeň v arabských službách najneskôr od čias Justiniána (Hurbanič 2020, 33). Dodnes však najrozsiahlejšie dielo o rímsko-arabských vztahoch v 6. storočí napísal Irfan Shahid. Pozri Shahid 1995-2009.

${ }^{7}$ Taxiarchis 1984, 129; pre vývoj literatúry v období Macedónskej dynastie, pozri Dostálová 2003, 156-182. 
sú o jeho priamom autorstve pochybnosti. ${ }^{8}$ Dielo však bolo určené jeho synovi a následníkovi Romanovi II. (959-963) ako praktická príručka o susedných národoch. ${ }^{9}$ Obsahuje 53 kapitol, v ktorých sa nachádzajú správy o rôznych národoch a ich politike, zvykoch, ale aj histórii. Správy sa týkajú nielen susedov Byzancie, ale aj vzdialených krajín ako Španielsko.

O Araboch pojednávajú kapitoly 14-22. Dielo sa však sústredí na dejiny Arabov od proroka Mohameda až do 9. storočia a informáciami o Islame, respektíve jeho vnímaniu v Byzancii. Vo všeobecnosti však aj ked' dielo obsahuje menej etnografických informácií ako Taktika, stále v ňom možno nájst’ odraz byzantského vnímania Arabov.

Posledné dielo, ktoré budem rozoberat, je História Leva Diakona. ${ }^{10}$ Od vyššie zmienených diel sa líši v dvoch smeroch. $\checkmark$ prvom rade nejde o encyklopedické zhrnutie informácií, ale o historické dielo, sústrediace sa na vlády cisárov Nikefora II. Fóku (963-969) a Jána Tzimiska (969-976). Vlády oboch cisárov sa spájali s vítaznými vojnami proti rôznym nepriatel'om, medzi inými aj Arabom. Nie je teda prekvapením, že dielo obsahuje isté stereotypy ohl'adom arabských protivníkov.

\footnotetext{
${ }^{8}$ Warren Treadgold poukázal na odopretie vzdelania pre Konštantína VII. po tom, čo Romanos Lekapenos získal trón. Konštantín si najal rôznych vzdelancov, aby vypracovali diela, často pripisované jemu. Pozri Treadgold 2013, 154-156. O celkovom charaktere DAI písal Anthony Kaldellis vo svojej knihe Ethnography After Antiquity: Kaldellis 2013, 93-98; dielo rozoberá aj štúdia Komatina 2019.

${ }^{9}$ Kaldellis 2013, 87-88.

${ }^{10}$ Lev Diakon patrí medzi menej preskúmané diela v rámci byzantskej historiografie. Najširšiu analýzu možno nájst v úvode prekladu do anglického jazyka z roku 2005: Leo the Deacon 2005, 1-52. Istým literárnym problémom sa venovali štúdie Martina Hinterbergera a Athanasios Markopoulos: Hinterberger 2016; Markopoulos, 2004. O Levovi Diakonovi píše Markopoulos aj vo svojej štúdii Markopoulos 2009.
} 
Druhý rozdiel tkvie $v$ osobe autora. Zatial' čo $v$ prípade prvých dvoch išlo o cisárov $\mathrm{s}$ prístupom $\mathrm{k}$ cisárskym archívom, Lev Diakon bol pôvodom z maloázijskej dediny Kaloe.. ${ }^{11} \mathrm{Aj}$ ked' v priebehu života získal vzdelanie a stal sa členom palácového kléru, ${ }^{12}$ predsa len pochádzal zo skromnejších pomerov, čo sa, ako sa uvidí nižšie, odrazilo aj v jeho diele.

Cez tieto tri diela približime byzantské pohl'ady na Arabov v 10. storočí. Ich analýza môže približit problematiku etnografie Arabov $v$ stredobyzantskom období, ktorá prešla výraznými zmenami od čias staroveku. ${ }^{13}$ Pozrieme sa na tri dôležité prvky, ktoré ovplyvnili byzantský opis Arabov - náboženstvo, vojenstvo a etnické stereotypy.

\section{Arabi ako moslimovia}

Arabi neboli neznámym fenoménom v Byzancii. Správy o nich nám podávajú rôzni starovekí (Klaudios Ptolemaios) ako aj neskoroantickí autori (Ammianus Marcellinus, Prokopios).

${ }^{11}$ Introduction v Leo the Deacon 2005, 9.

${ }^{12}$ Pravdepodobne bol ordinovaný v roku 975. S určitostou však môžeme povedat', že bol Diakonom na cisárskom dvore v čase t’aženia Basila II. (976-1025) do Bulharska v roku 986. Pozri Treadgold 2013, 236-237.

${ }^{13}$ Pre stredobyzantskú etnografiu je typický úpadok oproti svojej starovekej predchodkyni. Namiesto rozsiahlych informácií sa objavujú útržky etnografie naprieč prameňmi, ktoré spolu môžu vytvorit koherentnejší obraz. Pozri Kaldellis 2013, 34. Dôvody pre etnografické ticho v prameňoch možno hl'adat vo výrazných geopolitických zmenách v 7. storočí, následkom čoho bolo aj „doba temna“, ktorá sa vyznačovala úpadkom vzdelanosti a školstva v Byzancii a tým pádom aj literárnej produkcie. Pozri Dostálová 2003, 144; Anthony Kaldellis však poukázal vo svojej knihe na skutočnost', že Byzantínci mali zdroje informácií o cudzích národoch a etnikách. Pozri Kaldellis 2013, 26-43. Geopolitické zmeny 7. storočia boli ranou pre byzantskú ríšsku ideológiu, po ktorej už de facto nevystupovala z pozície mocnosti voči oným národom. Toto platilo obzvlášt pre Arabov, ktorí sa v priebehu niekol'kých rokov stali hlavnou mocnostou východu aj na úkor Byzancie. 
Byzantskí autori teda mali k dispozícii informácie ohladom tohto etnika.

Rozmach kalifátu $v$ 7. storoč $i^{14}$ zmenil nielen geopolitickú situáciu vtedajšieho sveta, ale mal dosah aj na zmýšlanie Rimanov, ktorí nikdy predtým nezažili podobnú porážku. ${ }^{15}$ Byzantski autori by nemohli podávat etnografický opis Arabov z mocenskej pozície, ako to bolo v minulosti, ${ }^{16}$ ale z pozície porazeného. Ich ideologický svet mocnej ríše ako náprotivok voči slabším "druhým“ sa rozpadol, ked' boli „tými druhými“ porazení.

Arabi sa vd'aka expanzii $v 7$. storoči stali priamymi susedmi Byzancie a jej najvážnejším protivníkom. Obidva štáty neustále medzi sebou viedli boje, či už išlo o mohutné vojny alebo o koristnícke nájazdy, ale mali aj obchodné a kultúrne kontakty. ${ }^{17}$ Vd'aka tomu, ako aj vd'aka starovekých autoroch obyvatelia byzantského štátu o Araboch vedeli. ${ }^{18}$ Autori tak nemali dôvod predstavit etnikum, ktoré ich čitatelia poznali.

\footnotetext{
${ }^{14}$ Pre arabské výboje do Byzancie a Perzie, pozri Hurbanič 2020, 214-223.

${ }^{15}$ Strata západorímskych území v 5. storočí v prospech novovznikajúcich germánskych král'ovstiev, ani zosadenie posledného západného cisára v roku 476, nepredstavovali v očiach Rimanov vo východnej časti ríše tak významné udalosti, za aké ich pokladali neskôr l'udia Západnej Európy. Germánski vládcovia na obsadených územiach formálne uznávali nadvládu cisárov v Konštantínopole, z poverenia ktorých vládli na svojich územiach. Pozri Kaldellis 2013, 73; Zástěrová et al. 1992, 57.

${ }^{16}$ Pozri napr. Ammianus Marcellinus, XIV. 4.

${ }^{17}$ Ako príklad kultúrnych výmen možno spomenút cisára Teofila (829-842), ktorý obdivoval arabskú kultúru a tak posielal vyslancov do Bagdadu, aby získal poznatky o jeho umeleckom a architektonickom štýle; Gregory 2005, 209.

${ }^{18}$ Práve tu možno hl'adat' d'alší dôvod pre etnografické ticho v prameňoch autori sa sústred'ovali viac na nové etniká v byzantskom orbite. Ako príklad možno uviest' príklad krátky etnografický opis Pečenehov, ktorý vo svojom diele podáva Michal Psellos. Pozri Psellos 1982, 67-69. Po jeho informácii už nebolo potrebné pre d'alších autorov, aby opísali etnikum, ktoré už predstavil Psellos. Anna Komnena, oboznámená so Psellovým dielom (pozri Neville 2018, 175) už teda nemala potrebu približit čitatel'om Pečenehov, ale sústredila sa na nové elementy v byzantskom orbite, ako boli Normani.
} 
To však neplatilo o novom náboženstve. Krestanskí autori už v počiatkoch arabskej expanzie badali, že dobyvatelia sú hnaní náboženským zápalom. ${ }^{19}$ Nové náboženstvo sa tak dostalo do pozornosti byzantských autorov, ktorí vnímali Islam ako herézu, o čom svedči aj jeruzalemský patriarcha Sofronios, ktorý piše že „...[Arabi] zväčšujú svoje rúhanie Krista a cirkvi a prejavujú odporné rúhania voči Bohu. " ${ }^{20}$ Islam teda Byzantínci vnímali v negatívnom svetle, čo sa odráža aj na neskorších prameňoch.

Najväčšiu pozornost mu však venovali krestanskí autori na teologickom poli. Vo väčšine prípadov išlo o teologické útoky voči novému náboženstvu, ale aj apologetické spisy, v ktorých autori obhajovali krestanstvo voči Islamu. ${ }^{21}$ Problémom bolo, že mnohokrát boli byzantské znalosti o Islame povrchné, alebo skreslené. Polemiky mohli byt písané bez toho, aby sa ich autor niekedy stretol s moslimom. ${ }^{22}$ Autori iných žánrov, ako napríklad historiografia, nemuseli a vel'akrát ani nemali záujem ukázat Islam v jeho reálnej podobe. Moslimov zobrazovali byzantskí autori ako heretikov, vyznávajúcich falošného proroka a jeho bludárske učenie.

Tento obraz podáva aj encyklopedické DAI. Jeho autor podáva v 14. kapitole opis o prorokovi Mohamedovi a pôvode Islamu, v ktorom možno bádat byzantský pohlad. O prorokovi sa píše: „Kedže ale [Mohamed] trpel chorobou epilepsie, jeho manželka, urodzená a bohatá dáma, bola vel'mi sklamaná, že bola zjednotená s týmto mužom.... tak ju on oklamal tvrdením : <Vidím strašné zjavenie anjela zvaného Gabriel, a neschopný vydržat jeho pohlad, som zakolísal a spadol>; a bolo mu uverené, pretože istý Arian, ktorý predstieral, že je mních, falošne svedčil

\footnotetext{
${ }^{19}$ Griffith 2008, 24.

${ }^{20}$ Sofronios v Hoyland 1997, 73.

${ }^{21}$ Pozri Griffith 2008, 35n.

${ }^{22}$ Kaldellis 2013, 76.
} 
$v$ jeho [Mohamedov] prospech..." ${ }^{23} Z$ daného úryvku možno badat', že v Byzancii považovali Mohameda za podvodníka, ktorý chcel oklamat ženu. Ďalej piše autor DAI o šírení prorokovho učenia: „...a jeho [Mohamedov] odporný podvod a heréza sa uchytila v oblasti Ethribos. A šialený a pomýlený človek učil tých, ktorí mu verili, že ten, kto zabije nepriatel'a alebo je zabitý nepriatel'om, vstúpi do raja, a zvyšok jeho nezmyslov. “24

Z poslednej citovanej vety možno vyvodit d'alší prvok pre byzantský obraz Islamu. Byzantínci si boli vedomí, že náboženstvo bolo jedným z hlavných motívov pre arabské nájazdy. Svedči o tom aj správa z diela Taktika: „Lebo Saracéni nejdú na taženie z nevol'níctva a vojenskej služby, ale skôr pre lásku k zisku a slobody alebo, lepšie povedané, pre lúpež a pre ich vlastnú vieru, alebo skôr bohabojnej úcty k ich neviere.“"25

Taktika neskôr podáva d'alší obraz Islamu ako heretického náboženstva: „Pokial' ide o ich božstvo, tomu preukazujú náležitú úctu, ale ich zjavná úcta musí byt považovaná za rúhanie. Nedokážu nazývat Krista Bohom (napriek tomu, že ním je), pravým Bohom a spasitel'om sveta. Tvrdia, že Boh je príčinou každého zlého skutku a vravia, že Boh má radost' vo vojne a rozptyluje l'udí, ktorí chcú bojovat," za hranice. " 26

Podla Johna Haldona odrážajú tieto tvrdenia prvky zavedenej krestanskej polemiky proti Islamu. ${ }^{27} \mathrm{Aj}$ ked'sa v tvrdeniach do istej miery odráža skutočnost, ${ }^{28}$ ide o skreslený obraz nábožen-

\footnotetext{
${ }^{23}$ De administrando imperio, 14. 77-79.

${ }^{24}$ Ibid. 79.

${ }^{25}$ Taktika, XVIII. 24.

${ }^{26}$ Ibid. 105.

${ }^{27}$ Haldon 2014, 353.

${ }^{28}$ Čast' vety „a rozptyluje l'udí, ktorí chcú bojovat', za hranice“ predstavuje moslimské delenie sveta na Dar al-Islam (svet Islamu) a Dar al-Harb (svet vojny). Pozri Armstrong 2002, 30.
} 
stva, ktoré predstavovalo protipól voči krestanskej viere. Kolias Taxiarchis spomína, že rozdiely v náboženstve, ako bezbožnost’ Arabov mali slúžit pre Levových velitel'ov k posilneniu morálky a bojovnosti vojakov. ${ }^{29}$ Ide teda o stereotypné delenie sveta na „My“ a „Oni“, pričom krestanstvo má predstavovat protipól nového náboženstva.

Byzantský obraz Islamu doplňuje Lev Diakon z druhej polovice 10. storočia, ktorý v súvislosti s krétskymi Arabmi píše: „hovorí sa, že Krétania sú závislí od veštenia, grobianstva a nesprávnej viery, ktoré sa kedysi naučili od Manichejcov a od Mohameda“. ${ }^{30}$ Zaujímavé je odvodenie islamskej viery od manicheizmu. Išlo o dualistickú vieru založenú na konflikte medzi Dobrom a Zlom. ${ }^{31}$ Proti manichejskému učeniu sa postavili mimo iných aj krestania, podla ktorých manichejci verili, že Kristus sa zjavil iba ako človek. ${ }^{32}$ Práve tu možno hl'adat' podobnost' s Islamom, ktorý Ježiša Krista považuje za proroka. O tomto aspekte Islamu v Byzancii vedeli, o čom svedčí aj vyššie uvedený citát z Taktiky.

Už byzantský pohlad na Islam naznačil d'alší významný prvok, ktorý výrazne ovplyvnil byzantské vnímanie Arabov v stredobyzantskom období - vojenstvo. Arabská ofenzíva v 7. storočí, ako aj neustále nájazdy do byzantského vnútrozemia výrazne ovplyvnili byzantské vnímanie Arabov. Vojenské akcie najviac prispeli k vytvoreniu etnických stereotypov o Araboch, ktoré sú odrazené v prameňoch.

${ }^{29}$ Taxiarchis 1984, 130-131.

${ }^{30}$ Leo the Deacon, II. 6.

${ }^{31}$ Kazhdan 1991, 1285-1286.

${ }^{32}$ Louth 2010, 189. 


\section{Vojenská etnografia Arabov}

DAI podáva vo svojej 15. kapitole informácie o Fatimovskom kmeni, ktorý však rozlišuje od afrických Fatimovcov svojej doby. Pri ich opise sa vyskytuje vojenská charakteristika Arabov: „Oni [Fatimovci] sú arabský národ, starostlivo vycvičení do vojen a bojov...lebo sú to odvážni muži a bojovníci, takže ak ich je číslom tisíc vo vojsku, vojsko nemôže byt porazené ani zmetené." ${ }^{33}$

George Theotokis poukázal na podobnost' u loanna Kaminiata, ktorý tiež opísal Arabov ako odvážnych bojovníkov. ${ }^{34}$ Odlišný opis však podáva Taktika, podl'a ktorej sú Arabi „odvážni pri očakávaní vít’azstva, ale vel'mi zbabelí ked'im je vít’azstvo odopreté. " 35 Vidiet tu kontrast medzi Taktikou na jednej strane a DAI a Kaminiatom na strane druhej. DAl ako aj Kaminiates však písali v rámci odlišného kontextu. Prvé menované dielo tým chcelo vysvetlit arabské úspechy počas ich expanzie. loannes Kaminiates bol na druhej strane priamym svedkom arabského dobytia mesta Thessaloniki. ${ }^{36}$ Opísaním Arabov ako odvážnych bojovníkov vylepšili reputáciu Rimanov, ktorí zlyhali voči arabskému tlaku.

Taktika však pokračuje d’alej v charakteristike Arabov v záležitostiach vojny. Píše: „Oni [Arabi] stoja pevne vo svojej formácii, znášajúc udatne strely vystrelené jednotkami smelo na nich útočiacich. Ked' badajú, že sily ich protivníkov ochabujú, vtedy povstanú a bojujú z celých síl...pri útoku na týchto l'udí je vždy nevyhnutné byt' pripravený na čokolvek. " 37 Z tejto správy vyplýva disciplína a nevyspytatel'nost' Arabov v očiach Rimanov. Prvú

\footnotetext{
${ }^{33}$ De administrando imperio, 15. 79.

${ }^{34}$ Theotokis 2018, 116.

${ }^{35}$ Taktika, XVIII. 112.

${ }^{36}$ Theotokis 2018, 113.

${ }^{37}$ Taktika, XVIII. 116.
} 
vlastnost potvrdzuje aj d’alši odsek, kde sa píše: „Sú význačnejší ako iní ludia v spoliehaní sa na dobrú radu a pevné zachovávanie metód vojenstva..." 38

Z hladiska vojenstva tak vyjadruje autor Taktiky rešpekt voči moslimským protivníkom, ked' ich popisuje ako dobrých bojovníkov, ktorí inteligenciou prekonávajú iné národy. ${ }^{39} \mathrm{Na}$ rozdiel od DAI a Kaminiatovho diela však Lev VI. nemal potrebu vyzdvihovat Arabov s cielom zlepšenia obrazu Rimanov po katastrofálnych porážkach. V snahe vytvorit vojenský manuál, v ktorom je opísaný spôsob boja protivníka, a o ktorom sa predpokladalo, že poslúži v praxi, poukázal autor na pozitívne bojové vlastnosti Arabov, s ktorými mali velitelia počítat.

História Leva Diakona je od predchádzajúcich diel odlišná. Prvýkrát spomína „Hagarénov“ v súvislosti s výpravou pod vedením Nikefora Fóku proti Arabom z Kréty. ${ }^{40}$ Hned' v prvej zmienke ich opisuje, že „boli arogantní a mali vražedné úmysly voči Rimanom. "41 Na prvý pohlad vyzerá charakteristika ako etnický stereotyp. Lev pripisuje arogantné správanie aj ruskému kniežatuu Sviatoslavovi (962-972). ${ }^{42}$ Bulharov nazval v 10. knihe ako „títo arogantní a krutí l'udia“. ${ }^{43}$ Všetky tri príklady sú uvedené v kontexte útokov a otvoreného nepriatel'stva voči Rimanom. Arogancia tak nebola typickou vlastnostou Arabov, ale išlo o vlastnost pripisovanú všetkým, ktorí otvorene vystúpili proti Byzantskej ríši.

\footnotetext{
${ }^{38}$ Taktika, XVIII. 117.

${ }^{39}$ Theotokis 2018, 121.

${ }^{40}$ Krétu dobyli v roku 826/828 Arabi z Andalúzie, ktorí tam zriadili základňu pre svoje pirátske útoky, ktorými sužovali Egejskú oblast', čím narušili byzantský obchod. Gregory 2005, 206-207.

${ }^{41}$ Leo the Deacon, I. 2.

42 „Sphendosthlavos bol vel'mi nafúkaný pre jeho vítazstvá nad Mysanmi [Bulharmi] a drzo sa chvastal s barbarskou aroganciou..." In Leo the Deacon VI, 10. ${ }^{43}$ Leo the Deacon, X. 8.
} 
Kontext „vražedné úmysly“ Arabov voči Rimanom sa objave ešte neskôr v prvej knihe Leva Diakona v súvislosti s príhovorom Nikefora Fóku svojim vojakom v kontexte obliehania Chandaku (dnešné Iraklio, Kréta). ${ }^{44} \mathrm{~V}$ reči spomenul, že „Prozretel'nost $\checkmark$ žiadnom prípade netoleruje, aby sa títo klamári, tieto najhoršie zvery, títo leniví nenažranci živili navždy krestanským ludom..."45 Lev Diakon tak cez reč Nikefora Fóku opät zobrazuje Arabov ako ludí, ktorí chcú zabíjat a plienit Rimanov a krestanov.

Podla Georga Theotokisa odráža Levov opis typický byzantský stereotypný pohlad na Arabov ako bojovníkov džihádu. ${ }^{46}$ Ich obraz je vo všeobecnosti negatívny; pozitivna referencia Arabov sa týkala ich materiálnej kultúry a umeleckej zručnosti. ${ }^{47} \mathrm{Tu}$ sa však naskytuje otázka, či sa jednalo o všeobecný byzantský obraz Arabov, alebo obraz v rámci jednej skupiny.

Lev Diakon bol členom kléru na cisárskom dvore Basila II. ${ }^{48}$ Prenikol tak medzi vyššie a vzdelané vrstvy byzantskej spoločnosti. Práve v rámci týchto vrstiev museli byt prítomné hlbšie znalosti o Araboch. Medzi týmito lud'mi boli diskusie o Araboch (a celkovo cudzincoch) založené na pragmatickosti, informáciách ako aj skúsenostiach. ${ }^{49}$ Je teda nepravdepodobné, že Lev nadobudol svoj zjednodušený stereotypný pohlad práve tam.

V úvode svojho diela piše Lev, že je synom istého Basila a pochádza z dediny Kaloe (dnes Kiraz, Turecko) na západe Malej Ázie. ${ }^{50}$ Podla Warrena Treadgolda musel byt jeho otec bohatým

${ }^{44}$ Chandak bolo hlavné mesto arabskej Kréty a hlavným ciel'om Fókovho útoku. Mesto bolo oblahnuté v roku 960 a 7. marca 961 napokon padlo do byzantských rúk. Pozri Zástěrová et al. 1992, 173.

${ }^{45}$ Leo the Deacon, I. 6.

${ }^{46}$ Theotokis 2018, 121.

${ }^{47}$ Leo the Deacon, II. 8.

48 Treadgold 2013, 237.

${ }^{49}$ Kaldellis 2013, 74.

${ }^{50}$ Leo the Deacon, I. 1. 
statkárom, ked' mohol synovi zaplatit štúdium v Konštantínopole. ${ }^{51}$ Pravdepodobne nepatril k významnejším aristokratom, kedže Lev nespomína rodinné meno svojho otca, ale patril k zámožnejším lud'om na lokálnej úrovni.

Levov pejoratívny a zjednodušujúci pohl'ad na Arabov možno hladat práve $v$ jeho pôvode. Bol to človek z maloázijského vidieka. Pravdepodobne vedel o pravidelných arabských nájazdoch do vnútrozemia Malej Ázie a tým pádom aj potenciálneho nebezpečenstva pre jeho rodisko. Lev pravdepodobne nikdy sám nezažil arabský útok ani obliehanie..$^{52} \mathrm{Na}$ cisárskom dvore mali zaiste lepšie znalosti o Araboch, ako aj o ich spôsobe boja. Lev tak mohol získat svoj stereotypný pohlad na arabských útočníkov iba v oblasti, ktorá arabský útok aspoň v priebehu jeho života nezažila, ale zároveň v ktorej bolo nebezpečenstvo potenciálneho arabského útoku prítomné..$^{53}$

V tomto tkvel aj zásadný rozdiel medzi Levom Diakonom a cisárom Levom VI., ako aj autorom DAI. Zatial' čo poslední uvedení mali odjakživa prístup k cisárskym a tým pádom kvalitnejším zdrojom, Lev mal svoj pohlad utvorený z vidieckeho prostredia. Vojny na východe pod vedením Nikefora Fóku, Jána Tzimiska, alebo Basila II. jeho negatívny pohlad pravdepodobne iba utvrdili.

Uviedli sme teda byzantský obraz Arabov z náboženského, ale aj vojenského hl'adiska. Avšak ako bolo naznačené v prípade pozitívneho obrazu Leva Diakona na arabskú materiálnu kultúru,

${ }^{51}$ Treadgold 2013, 236.

52 Theotokis 2018, 117.

${ }^{53}$ Arabským nájazdníkom sa v minulosti podarilo preniknút až do západnej časti Malej Ázie. Svedčí o tom napr. nájazd v Lýdii v roku 799 (Foss 1976, 62), ako aj ohrozovanie maloázijského pobrežia arabskými pirátmi. Tieto nájazdy mohli byt aj z dôvodu kontinuity arabských nájazdov v kolektívnej pamäti obyvatel'ov Malej Ázie živé aj v čase, ked' konkrétne oblasti arabský útok už dlhšie nezažili. 
v Byzancii existoval obraz Arabov odlišný od oboch zmienených hladísk. $V$ tomto obraze možno nájst odraz bežných etnických stereotypov.

\section{Etnické stereotypy?}

Etnické stereotypy o Araboch mimo náboženského a vojenského pohl'adu sa v prameňoch nachádzajú $v$ zriedkavejšej forme. DAI obsahuje iba jednu informáciu, prebratú z Theofanovej kroniky, podla ktorej bol prsteň znakom vlády Arabov. ${ }^{54}$ Ostatné informácie sa zaoberajú históriou Arabov, bez etnografie.

História Leva Diakona obsahuje viac stereotypných informácií ohladom Arabov. Až na vyššie uvedenú výnimku s obdivom k materiálnej kultúre je obraz Arabov pejoratívny. Už vyššie bol spomenutý Levov opis Arabov v rámci príhovoru Nikefora Fóku ako "klamárov, tieto najhoršie zvery, týchto lenivých nenažrancov". 55

V tom istom príhovore sa spomína aj „krutost' a divokost potomkov slúžky. “56 Aj ked' adjektívum „krutost“" možno radit aj medzi vojenské stereotypy, "divokost" môže označovat" všeobecnú vlastnost Arabov. Čo sa týka "slúžky“, Lev nemal namysli nikoho iného ako biblickú Hagar, Abrahámovu egyptskú slúžku. ${ }^{57}$

\footnotetext{
${ }^{54}$ De administrando imperio, 21. 91.

${ }^{55}$ Leo the Deacon, I. 6.

${ }^{56} \mathrm{Ibid}$.

${ }^{57} \mathrm{Gn}, 16,1$; Abrahám počal s Hagar syna Izmaela (Gn 16, 15), ktorého dvanást’ synov židovskí a ranokrestanskí spisovatelia spájali s dvanástimi arabskými kmeňmi (pozri Tolan 2002, 11). Od toho bolo odvodené ich pomenovanie Hagaréni. Lev Diakon použiva toto označenie naprieč celým svojím dielom. Alexis Savvides tvrdí, že týmto termínom sa označovali Arabi/moslimovia obzvlášt z krétskeho emirátu ako aj severnej Afriky v 9., 10. a 11. storočí. Pozri Savvides 1997, 90.
} 
Zaujímavá je pasáž o obliehaní Mopsuestie (Eski Misis, Turecko). V nej spomína Arabov "ako zvyčajne v bielej róbe“. ${ }^{58}$ Táto etnografická informácia však môže súvisiet s Levovými skúsenostami s Arabmi. Biele šaty boli vyžadované od arabských vojnových väzňov..$^{59}$ Lev Diakon mohol stretnút práve týchto Arabov v čase jeho kariéry na cisárskom dvore. Kvôli absencii predchádzajúcich skúseností s Arabmi mohol bielu róbu považovat za ich typický etnický odev.

Taktika obsahuje popri vojenských informáciách aj vel'ké množstvo etnických stereotypov. Oproti DAl a Levovi Diakonovi však obsahuje aj charakterizáciu založenú na environmentálnej teórii. ${ }^{60} \mathrm{~V}$ jednom prípade sa píše, že arabský temperament je "horúci, pretože prebývajú v takom horúcom podnebi".61 O niečo neskôr píše autor o Araboch, že „im ubližuje chlad, zima a silný dážd' "“62 Aj ked' d'alej rozvíja svoju tézu s ohl'adom na vojenstvo, konkrétny úryvok možno považovat' za etnický stereotyp.

John Haldon poukázal na skutočnost', že oba príklady environmentálneho stereotypu boli odvodené zo Pseudo-Mauríkiovho Strategikonu, kde sa však týkali Peržanov. ${ }^{63}$ Taktika patrí medzi d'alšie príklady toho, ako v byzantských očiach nahradili Arabi Peržanov nielen ako úhlavní nepriatelia, ale aj v charakterových vlastnostiach.

\footnotetext{
${ }^{58}$ Leo the Deacon, III. 11.

${ }^{59}$ Pre informácie o arabských vojnových väzňoch v Byzancii, pozri Simeonova 1998, 75-104.

${ }^{60}$ Išlo o grécko-rímsku teóriu vyvinutú v staroveku, podla ktorej boli charakterové skupiny l'udí prepojené s fyzickým prostredím, z ktorého pochádzali. Isaac 2004, 55-56.

${ }^{61}$ Taktika, XVIII. 108.

62 Ibid. 118.

${ }^{63}$ Haldon 2014, 356, 361-362.
} 
Zaujímavá sa javí pasáž o dôvodoch arabských nájazdov. Podla autora chcú Arabi popri sláve získat aj zásoby, pretože sa „nevedia ako obrábat pôdu za účelom svojej záchrany od chudoby“. ${ }^{64}$ John Haldon poukázal, že táto informácia nie je úplne nepravdivá. Arabi z pohraničných oblastí, najmä vojenské jednotky $z$ thughur ${ }^{65}$ sa nezaoberali hospodárstvom, ale zo štátnych dotácií a z plienenia. ${ }^{66}$ Uvedená čast z Taktiky tak nemusí predstavovat etnický stereotyp o Araboch.

\section{Záver}

Cez tri byzantské pramene (Taktika, De administrando imperio a História Leva Diakona) sme mohli vidiet etnografické informácie o Araboch tak, ako ich vnímali v Byzancii 10 storočia. Odlišný charakter jednotlivých diel umožnil utvorit obraz Arabov z rôznych pohladov, ale aj odraz zmýšlania rôznych spoločenských vrstiev v Byzancii.

Etnografia Arabov bola ovplyvnená geopolitickými zmenami 7. storočia. Pri utváraní ich obrazu sa do popredia dostalo náboženstvo, ktoré v Byzancii vnímali ako hnací motor pre arabskú expanziu ako aj dôležitú súčast ich života, ako aj vojenstvo. Byzancia viedla s kalifátom ako hlavným mocenským konkurentom mnoho bojov, čo ovplyvnilo aj pohlad obyvatel'ov ríše na svojich východných susedov. Pravidelné nájazdy ako aj spomienka na arabskú expanziu zanechali stopu v byzantskej percepcii.

Oproti staroveku upadli etnické stereotypy o Araboch. Taktika ako jediné $z$ diel aplikuje na Arabov environmentálnu teóriu, čo bol dôsledok vplyvu Strategikonu. V dobe vytvorenia Taktiky

${ }^{64}$ Taktika, XVIII. 130.

${ }^{65}$ Pohraničné oblasti Kalifátu, pozri Haldon a Kennedy 1980, 106.

${ }^{66}$ Haldon 2014, 378-379. 
však Arabi nahradili Peržanov ako hlavného protivníka na východe, čím na tamtých boli prenesené viaceré vlastnosti, ktoré v staroveku pripisovali Peržanom. Environmentálna teória však v kontexte diela slúžila pre vojenské účely.

História Leva Diakona sa v popisovaní Arabov líši od svojich predchodcov. Dôvodom je aj pôvod autora. Zatial' čo Taktika a DAI vzišli z prostredia cisárskeho dvora, na ktorom pôsobili vzdelanci byzantského štátu, Lev Diakon bol pôvodom z dediny v Malej Ázii. Aj ked'v čase písania svojho diela mal kariéru na dvore Basila II., Lev sa mimo hlavného mesta nikdy nestretol s Arabmi. Jeho čisto negatívny obraz bol pravdepodobne ovplyvnený jeho pôvodom. Arabov vnímal ako agresorov, ktorí neuznávali Kristovo božstvo a ktorí z krutosti túžili zabijat krestanov. Maloázijské územie bolo terčom každoročných arabských nájazdov. V Levovej správe sa tak odráža zmýšlanie prostých ludí Anatólie, ktorí žili v strachu pred potenciálnymi alebo skutočnými arabskými útokmi. Autor však zažil Arabov iba v Konštantínopole, kde ich videl iba ako väzňov v bielej róbe. Skutočnost', že bielu róbu považoval za typickú pre Arabov všeobecne naznačuje, že mimo hlavného mesta sa s nimi nikde inde nestretol. $Z$ toho možno vyvodit', že jeho zobrazenie Arabov je založené na jeho predstavivosti, nadobudnutej či už z jeho vidieckeho pôvodu, ako aj z hlavného mesta.

Etnografia stredobyzantského obdobia si nad'alej vyžaduje d'alší výskum. Na príklade Arabov však možno vidiet, ako vonkajšie faktory ovplyvnili obraz etnika známeho byzantskému človeku už od čias staroveku. 


\section{Literatúra}

Ammianus Marcellinus. 1987. Rímske Dejiny. Preklad Daniel Škoviera. Bratislava: Tatran.

Constantine VII. Porphyrogenitus. 1967. De administrando imperio. Vyd. Gyula Moravcsik, preklad Romilly James Herald Jenkins. Washington D.C.: Dumbarton Oaks.

Hoyland, Robert. 1997. Seeing Islam as others saw it: A survey of evaluation of Christian, Jewish and Zoroastrian writings on early Islam. Princeton: The Darwin Press.

Leo the Deacon. 2005. The History of Leo the Deacon: Byzantine Military Expansion in the Tenth Century. Preklad Alice-Mary Talbot, Denis Sullivan. Washington D.C.: Dumbarton Oaks.

Leo VI. 2010. The Taktika of Leo VI. Preklad George Dennis. Washington D.C.: Dumbarton Oaks.

Michal Psellos. 1982. Byzantské letopisy. Preklad Růžena Dostálová. Praha: Odeon.

Armstrong, Karen. 2002. Islam: A short history. New York: The Modern Library.

Dostálová, Růžena. 2003. Byzantská vzdělanost. Praha: Vyšehrad. Foss, Clive. 1976. Byzantine and Turkish Sardis. Cambridge, Massachusetts - London: Harvard University Press.

Gregory, Timothy E. 2005. A History of Byzantium. Oxford: Blackwell Publishing.

Griffith, Sidney H. 2008. The Church in the Shadow of the Mosque: Christians and Muslims in the World of Islam. Princeton - Oxford: Princeton University Press.

Haldon, John. 2014. A Critical Commentary on the Taktika of Leo VI. Washington D.C.: Dumbarton Oaks.

Haldon, John F. a Hugh Kennedy. 1980. „The Arab-Byzantine Frontier in the Eighth and Ninth Centuries: Military Organisation and Society in the Borderlands." Zbornik Radova Visantološkog Instatuta 19: 79-116. 
Hinterberger, Martin. 2016. „Envy and Nemesis in the Vita Basilii and Leo the Deacon: literary mimesis or something more?" In History as Literature in Byzantium, vyd. Ruth Macrides, 187-206. London - New York: Routledge.

Hurbanič, Martin. 2020. Súboj Titanov - Nový Rím a Perzia: Supervel'moci starého sveta pred nástupom islamu. Bratislava: Veda.

Isaac, Benjamin. 2004. The Invention of Racism in Classical Antiquity. Princeton - Oxford: Princeton University Press.

Kaldellis, Anthony. 2013. Ethnography after antiquity: Foreign lands and peoples in Byzantine literature. Philadelphia: University of Pennsylvania Press.

Kazhdan, Alexander P. 1991. The Oxford dictionary of Byzantium, vol. 2. New York - Oxford: Oxford University Press.

Kolias, Taxiarchis G. 1984. „The Taktika of Leo VII the Wise and the Arabs." Graeco-Arabica 3: 129-135.

Komatina, Predrag. 2019. "Constantine Porphyrogenitus, De administrando imperio and the Byzantine Historiography of the mid-10th Century." Zbornik Radova Vizantološkog Instituta 56: 39-68.

Louth, Andrew. 2010. "Christology and Heresy." In A Companion to Byzantium, vyd. Liz James, 187-198. Malden: Wiley-Blackwell.

Markopoulos, Athanasios. 2004. "Gender issues in Leo the Deacon“. In History and Literature of Byzantium in the 9th and 10th Centuries, vyd. Athanasios Markopoulos, 1-16. Aldershot: Variorum.

Markopoulos, Athanasios. 2009. „From Narrative Historiography to Historical Biography: New Trends in Byzantine Historical Writing in the 10th - 11th Centuries." Byzantinische Zeitschrift 102: 697-715.

Nakada, Kosuke. 2017. „The Taktika of Leo VI and the Byzantine Eastern Frontier During the Ninth and Tenth Centuries." Spicilegium 1: 17-27. 
Neville, Leonora. 2018. Guide to Byzantine Historical Writing. Cambridge: Cambridge University Press.

Savvides, Alexis G. C. 1997. "Some notes on the terms Agarenoi, Ismaelitai and Sarakenoi in Byzantine sources." Byzantion 67: 89-96.

Shahid, Irfan. 1995-2009. Byzantium and the Arabs in the sixth century, vol. 1-2. Washington D.C.: Dumbarton Oaks.

Simeonova, Liliana. 1998. "In the depths of tenth-century Byzantine ceremonial: the treatment of Arab prisoners of war at imperial banquets." Byzantine and Modern Greek Studies 22: 75-104.

Theotokis, George. 2018. Byzantine military tactics in Syria and Mesopotamia in the 10th century. Edinburgh: Edinburgh University Press.

Tolan, John V. 2002. Saracens: Islam in the Medieval European Imagination. New York: Columbia University Press.

Treadgold, Warren. 2013. The Middle Byzantine historians. New York: Palgrave Macmillan.

Zástěrová, Bohumila, Alexander Avenarius, Růžena Dostálová, Vladimír Fiala, Věra Hrochová, Milan Loos, Oldřich Tůma a Vladimír Vavřínek. 1992. Dějiny Byzance. Praha: Academia.

\section{Summary}

\section{Ethnographic image of the Arabs in $10^{\text {th }}$ century Byzantium}

The research focuses on three 10th century sources. First of them is the Taktika of Leo VI (886-912), a military manual based on a sixth-century work Strategikon. The former's Constitution 18 contains ethnographic information about various nations. Among those, the Arabs were the only ones that weren't based on Strategikon. 
The second source is De administrando imperio ascribed to Constantine VII Porphyrogenitus (945-959). This manual about various nations or states contains information about the history of Arabs since the rise of Islam. And finally, the History of Leo the Deacon, which differs from the previous works in the matter of genre (for it is a historical work) and author (who had humble origins compared to the previous two).

The Byzantine perception of Arabs is analysed through three important elements - religion, military, and ethnic stereotypes. The first one occupies a vast space in Byzantine sources. Whilst Arabs as a people were well known to the Byzantines, the same cannot be said about Islam. Christian writers were aware, however, that the Arabs were pressed by a religious zeal during their conquests. The same conclusion can be found in Taktika. All three sources, however, simplistically treat Islam, considering it as heretical teaching founded by a liar.

The military ethnography provides the most varied perceptions. In DAl, the Arabs are considered as the brave and invincible army in the context of their conquests. The author(s) attempted to refine the picture of Byzantines, who suffered such great military losses.

The Taktika gives practical information about Arabic warfare. It describes them as courageous while winning, but cowardly when losing. Taktika also provides a positive picture of Arabs by stressing their discipline and unpredictability.

Leo the Deacon is describing Arabs in an utterly negative way as cruel and worst people with a desire to feed on Christian blood. The author, who himself came from an Anatolian village and who never seen an Arab apart from Constantinople, serves as a pattern for a perception of Arabs as it occurred among the ordinary 
village people of Asia Minor. The negative view was a result of constant fear of the Arab raid, which reached Anatolia annually. As for ethnic stereotypes, this category is the least represented in the sources. DAl only gives a hint that a ring is the sign of power among the Arabs. The History is slightly different. Apart from an admiration for their material culture, Leo the Deacon considers Arabs as cruel, wild, and lazy. Worth mentioning is the fact, that he calls them "Hagarenes" throughout his entire work.

An interesting hint is Leo the Deacon's attribution of white robes as typical Arab clothing. He was misled by the fact that Arab prisoners, whom he saw in the Capital, were assigned to wear white robes.

The Taktika is the only work that contains the environmental theory about Arabs, ascribing them hot temperature due to the climate they dwell in. This was inspired by the Strategicon, where the Persians possessed these attributes.

Each work had its specific features; the History of Leo the Deacon however may provide priceless information about the mentality of village people from Asia Minor. Other research of History is thus necessary. 